\title{
Mineralogical Appraisal of Sediments of Duricrust Suites and Pans around Jwaneng Area, Botswana
}

\author{
${ }^{1 *}$ ATLHOPHENG, JULIUS R; ${ }^{2}$ GEORGES-IVO E. EKOSSE \\ 1. Department of Environmental Science, University of Botswana, Private Bag UB0704 \\ Gaborone \\ 2. Geology, Mining and Minerals Programs, University of Limpopo, P/B X1106 Sovenga, 0727 South Africa
}

\begin{abstract}
A mineralogical investigation of duricrust suites in Letlhakeng valley, and five pans around Jwaneng in Botswana was undertaken in order to know the mineral assemblages and infer on their landscape formation. In Letlhakeng, duricrusts comprised calcretes, silcretes and ferricretes. Calcretes were dominated by the minerals: calcite, quartz and to a lesser extent dolomite. Silcrete mineralogy was dominated by quartz, opal, and some occurrences of palygorskite, microcline and rutile. The intermediate forms of cal-silcretes yielded quartz, muscovite, and kaolinite. Ferricretes occurred on an area of the valley capping, with minerals dominated by goethite and haematite. The indurates are believed to have been formed through groundwater mechanisms. The general lowering of the valley, led to precipitation of the duricrusts. The pans were dominated by calcrete and silcrete only. The calcretes mineralogy was mainly calcite, dolomite and quartz. Illite-montmorillonite and sepiollite were also present. Samples of pan clay floor, other than being dominated by calcite, dolomite and quartz, also had sepiollite ferrian. Pans and valleys are accumulation sites, with polygenetic modes of genesis. The duricrusts have undergone several alterations throughout time. @JASEM
\end{abstract}

Calcretes, silcretes and ferricretes are principal materials constituting duricrusts suites and pans. They are distinguished from one another by their mineralogy and modes of formation, and could sometimes have economic bearings. Most of the minerals are secondary and do affect landscape topography. Calcretes are found on the near surfaces and composed of $\mathrm{CaCO}_{3}$ varying from powdery to nodular highly indurated form (Wright and Tucker, 1991). It could be formed from either groundwater or pedogenetic activities. The non-pedogenetic calcrete may be known as groundwater, phreatic, valley or channel calcretes, with all of them relating to movement of sub-surface water, which could be lacustrine (pans) riverine or from water table. The processes often overlap in the natural environment. Silcretes may form predominantly from either surface or groundwater sources (Ollier, 1978). The silcrete may form as monosilicic acid, a colloid in pervious sediment or in weathered rock. Thus chemical weathering of silicate rocks is an important source of silcrete formation, so can solution of quartz dust. The cementing agent (silica) may be transported either laterally or vertically in groundwater, pore water and surface water. In arid environments, silica dissolved in water probably originated as quartz or silicates, mainly clays.

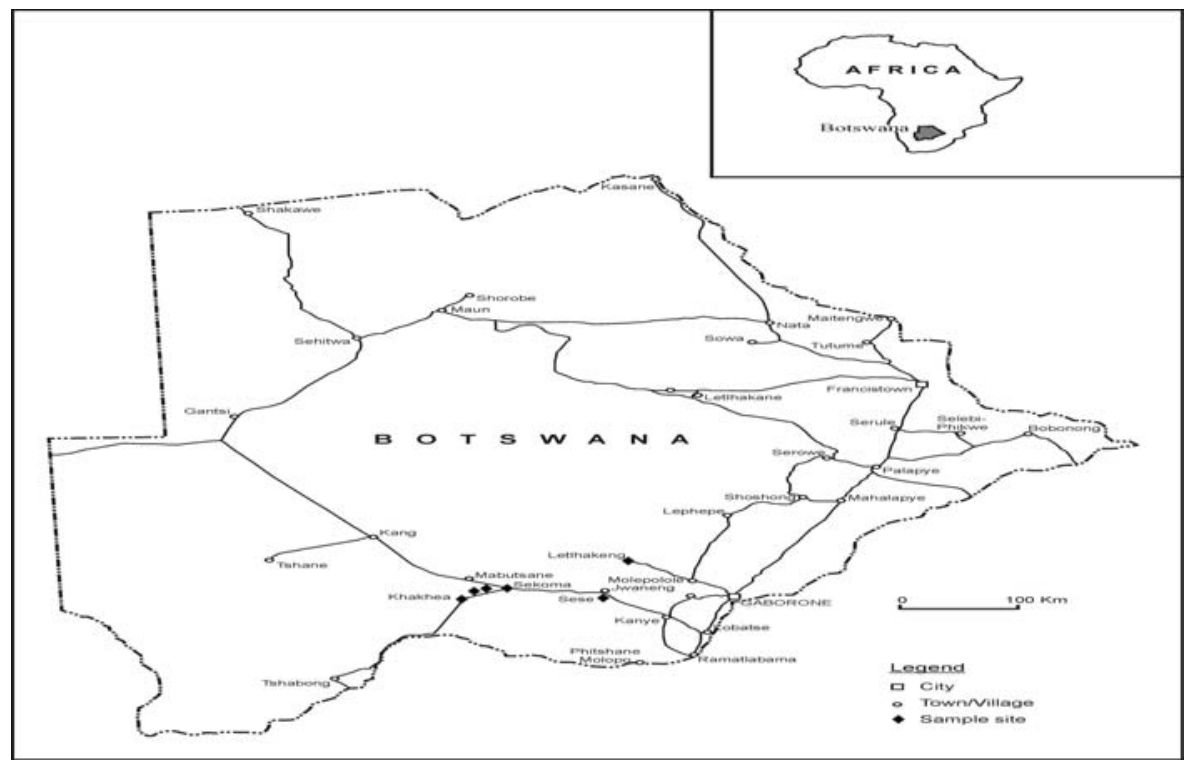

Fig 1: Map of Botswana showing sampling areas 
Ferricretes, having the minerals goethite, haematite, ferrihydrite, lepidocrocite and maghemite occur in nature, under varying environmental conditions. $\mathrm{Fe}$ mobilization is normally associated with wetter conditions than calcrete or silcrete. The formation of ferricretes may be related to landscape dynamics e.g. etching, down wasting and relief inversion. As such ferricretes have been used as morphostratigraphic markers (relative dating) - as has been for calcretes and silcretes (Young et al. 1996; Twidale and Bourne, 1998; Taylor and Howard, 1999; Twidale, 2002; Watchman and Twidale, 2002). All the three duricrusts suites formations may be aided by microorganisms. In ferricrete formation the microbes may rework (dissolution and reprecipitation) indurates resulting in a younger isotopic age of the $\mathrm{Fe}$ suites (Yapp, 2000).

In Botswana, due to its arid to semi arid climate, duricrusts dominate the topography especially close to the hinges of the Kalahari Desert. Although several duricrusts suites and pans exist in Botswana, no known mineralogical investigation has been carried out on them. This study therefore attempts to use mineralogy of sediments of duricrusts suites and pans close to the country's well known Kalahari Desert to infer on their formation.

\section{MATERIALS AND METHODS}

Sediment samples were obtained from fossil valleys and pans around the Jwaneng area, Botswana (Figures 1 and 2). The pans had variable associated landforms, namely lunette dunes. The location of the dunes tended to be on the south to south-west, inferring formative wind was from north to northeast. Ten samples were from Letlhakeng Fossil

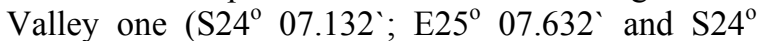
08.166 ; E25 ${ }^{\circ}$ 09.005') and two samples from Letlhakeng Fossil Valley two (S24 ${ }^{\circ} 09.701^{\prime}$; E25 ${ }^{\circ}$ $\left.04.879^{\prime}\right)$. Eleven samples were obtained from the Sese pan (S24 38.997 ; E $\left.24^{\circ} 48.825^{\prime}\right)$, nine samples from Sekoma pan (S24 $30.814^{\circ}$; E23 $\left.{ }^{\circ} 53.908^{\prime}\right)$, two samples from Keng pan (S24 $35.240^{\circ} ; \mathrm{E} 23^{\circ}$ $\left.44.918^{\circ}\right)$, two samples from Khonkhwa pan (S24 $33.724^{\prime}$; E23 ${ }^{\circ}$ 51.080') and two samples from Khakhea pan (S24 $\left.{ }^{\circ} 41.937^{\circ} ; \quad E^{\circ} 3^{\circ} 29.357^{\circ}\right)$.

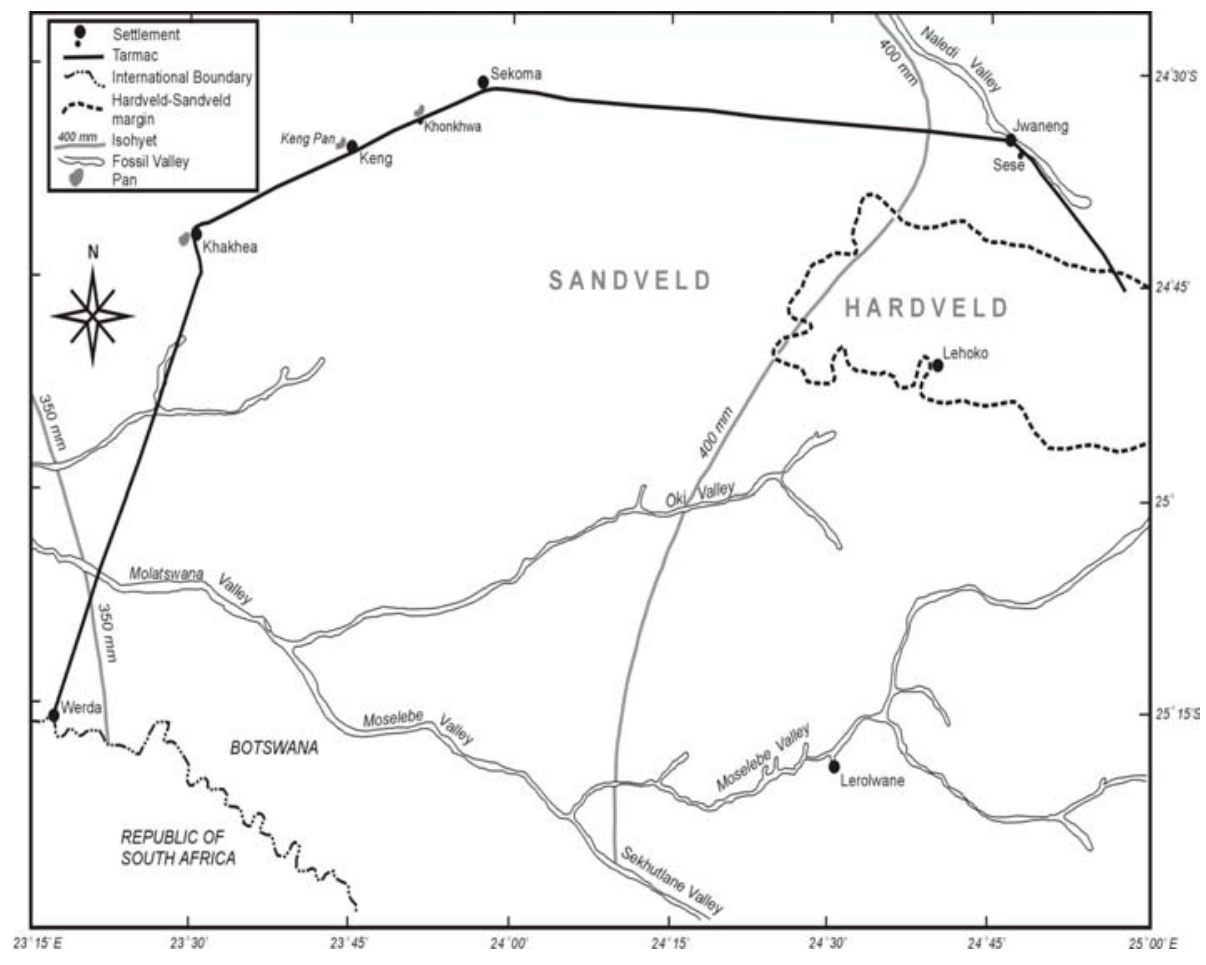

Fig 2: Base geomorphological map of the study area

X-ray powder diffractometry was the technique employed in identifying the sampled sediments. Samples for X-ray powder diffractometry tests were mounted on the sample holder with very little pressure, and later scanned in the XRPD equipment. Prior to mounting of the samples, they were pulverized in a Seib Mill to change their physical state from indurated hard material to fine powdery 
substance. The minerals in the samples were identified using a Philips PW 3710 XRPD X-ray diffractometer system, operated at $40 \mathrm{kV}$ and $45 \mathrm{~mA}$, having a $\mathrm{Cu}-K_{\alpha}$ radiation and a graphite monochromator. A PW 1877 Automated Powder Diffraction, X'PERT Data Collector software package was used for the capturing of raw data, and a Philips X'PERT Graphics \& Identify software package for qualitative identification of the minerals from both the data and patterns obtained by scanning at a speed of $1^{\circ} 2 \Theta / \mathrm{min}$. Samples were scanned from $2^{\circ} 2 \Theta$ to $70^{\circ} 2 \Theta$. The interpreted results were compared with data and patterns available in the Mineral Powder Diffraction File, data book (International Center for Diffraction Data (ICDD) (2001).

\section{RESULTS AND DISCUSSION}

Minerals identification: The results obtained by XRPD analyses are briefly presented in accordance with the different areas from which the samples were obtained. Representative diffrctograms from Sesi and
Sekoma samples are given in Figures 3 and 4 respectively. The samples from the Letlhakeng Fossil valley one were identified as silcrete, nodular silcrete, siliceous conglomerate, hard floor pan calcrete, and ferricrete. The silcrete consisted of quartz $\left(\mathrm{SiO}_{2}\right)$, calcite $\left(\mathrm{CaCO}_{3}\right), \mathrm{Ca}$ rich albite $\left((\mathrm{Na}, \mathrm{Ca}) \mathrm{Al}(\mathrm{Si}, \mathrm{Al})_{3} \mathrm{O}_{8}\right)$ and montmorillonite-15A $\left(\mathrm{Ca}_{0.2}(\mathrm{Al}, \mathrm{Mg})_{2} \mathrm{Si}_{4} \mathrm{O}_{10}(\mathrm{OH})_{2} * 4 \mathrm{H}_{2} \mathrm{O}\right)$. Quartz, opal $\left(\mathrm{SiO}_{2} * \mathrm{xH}_{2} \mathrm{O}\right)$ and palygorskite $\left(\mathrm{Mg}_{5}(\mathrm{Si}, \mathrm{Al})_{8} \mathrm{O}_{20}(\mathrm{OH})_{2} * 8 \mathrm{H}_{2} \mathrm{O}\right)$ were formed the nodular silcrete. The siliceous conglomerate comprised quartz, opal, calcite, dolomite $\left(\mathrm{CaMg}\left(\mathrm{CO}_{3}\right)_{2}\right.$, and rutile $\left(\mathrm{TiO}_{2}\right)$. The hard floor pan calcerte was composed of calcite and quartz; and the ferricrete consited of goethite $\left(\mathrm{Fe}^{+3} \mathrm{O}(\mathrm{OH})\right.$, hematite $\left(\mathrm{Fe}_{2} \mathrm{O}_{3}\right)$, quartz and microcline $\left(\mathrm{KAlSi}_{3} \mathrm{O}_{8}\right)$. The Letlhakeng Fossil valley two samples were silcrete and calcrete. The silcrete was made of quartz, kaolinite $\left(\mathrm{Al}_{2} \mathrm{Si}_{2} \mathrm{O}_{5}(\mathrm{OH})_{4}\right)$ and muscovite $\left(\mathrm{KAl}_{2} \mathrm{Si}_{3} \mathrm{AlO}_{10}(\mathrm{OH})_{2}\right)$; and the calcrete consisted of calcite and quartz.

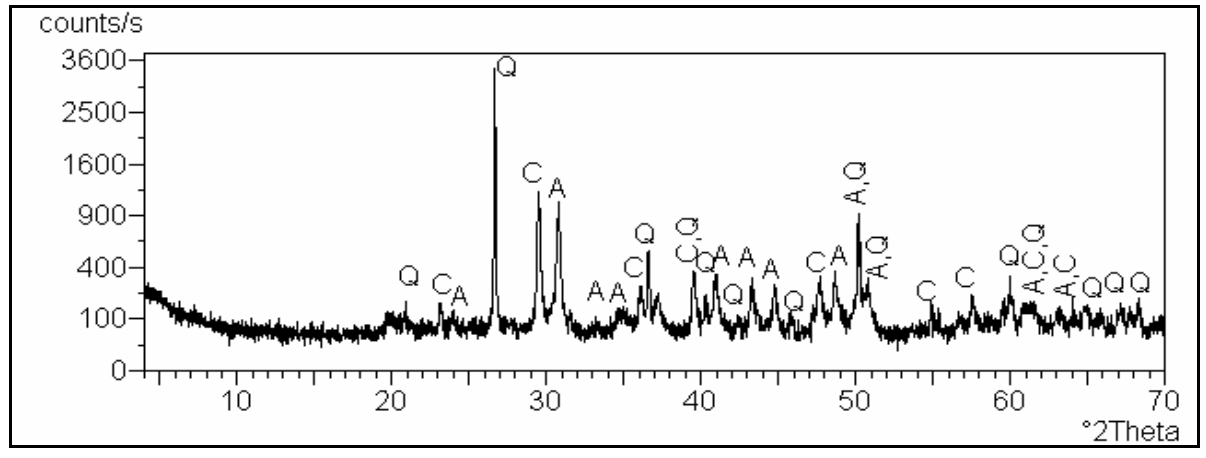

Fig 3: X-ray diffractogram of representative sample from Sese Pan $(Q=$ quartz, $A=$ ankerite and $C=$ calcite $)$

The Sese Pan samples were principally calcretic and they all contained calcite and quartz. Samples 7,8 and 9 also had ankerite $\left(\mathrm{Ca}\left(\mathrm{Fe}^{+2}, \mathrm{Mg}\right)\left(\mathrm{CO}_{3}\right)_{2}\right)$. The Sekoma Pan samples were calcretic with calcite being dominant in all the samples except for one sample (SEK 2); and quartz was present in all the samples except sample SEK 9.Dolomite was a major mineral constituent in sample SEK 2, and a minor mineral constituent in samples SEK 4 and SEK 6. Illite-montmorillonite $\left(\mathrm{KAl}_{4}(\mathrm{Si}, \mathrm{Al})_{8} \mathrm{O}_{10}(\mathrm{OH})_{4} * 4 \mathrm{H}_{2} \mathrm{O}\right)$ was identified in samples SEK 1, SEK 4, SEK 5 and SEK 6. The pan calcrete and clayey material from the pan floor were the two types of samples from the Keng Pan, Khonkhwa Pan and Khakhea Pan. The calcrete sample from Kheng Pan had calcite, quartz and sepiolite $\left(\mathrm{Mg}_{4} \mathrm{Si}_{6} \mathrm{O}_{15}(\mathrm{OH})_{2} * 6 \mathrm{H}_{2} \mathrm{O}\right)$; and the clayey material consisted of calcite, dolomite, quartz and sepiolite. Both the calcrete and clayey material from the Khonkhwa pan consisted of calcite, dolomite, quartz and sepiolite. Calcrete from Khakhea Pan comprised calcite and dolomite; and the clayey material had calcite, quartz and montmorillonite.

Calcretisation of sediments of the duricrust suites and pans: Calcrete is dominantly present in the study area. The occurrence of calcrete and its associated landforms has been discussed in relation to fossil valleys (Nash et al., 1994) and also in pans (Nettterberg 1978). The polygenetic nature of calcrete is best appreciated when erosion, dissolution and recrystallization are noted to be at the core of the calcrete formations. Calcretes are typified by calcite minerals, and the ubiquitous quartz. Some of the material suspected to be calcrete, also has dolomite, 
which is better explained in terms of more evaporative conditions.

Calcretes may vary in chemical composition from those with dolomite; the presence of clays and may be polygenetic, resulting in admixture of calcrete types as well as with silica. Those with silica admixtures tend to be regarded as sil-calcretes (Watson and Nash, 1997). Calcretes could be mobilized and precipitated, and affect landscape evolution. The carbonate source (dissolved) may be derived from topographic highs and precipitate out in the low ends. With time, this indurate would prove resistant to erosion, and possibly end up as a capping, hence the relief inversion. The mobilization of carbonate by groundwater or valley side processes, as resistant blocks may also lead to the same. The etching of the subterranean relief, with the area covered by duricrust, resting as a capping, may aid the same process, of having calcrete mass as cappings.

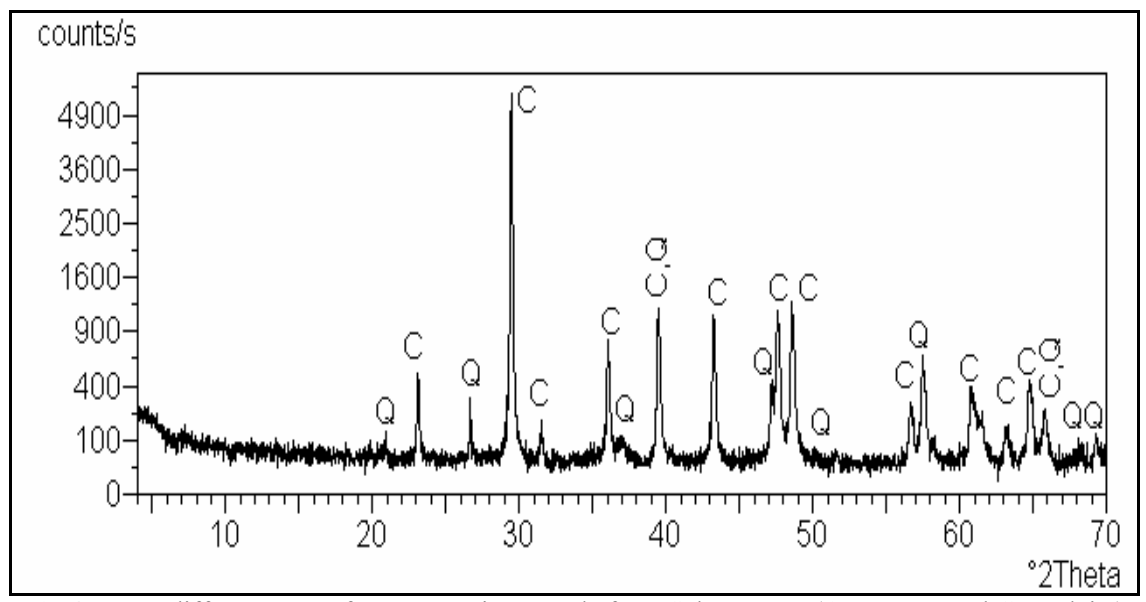

Fig 4: X-ray diffractogram of representative sample from Sekoma Pan $(\mathrm{Q}=$ quartz and $\mathrm{C}=$ calcite $)$

Silcretisation of sediments of the duricrust suites and pans: The analysed silcretes had quartz and opal. The latter may form in more mature silcretes, hence older. Silcrete formation results from silica precipitating as a result of $\mathrm{pH}$ drop, evaporation, as well as cooling and organic processes. Silcretes may also form under alkaline oxidising conditions by the crystobalitictridymitic silica cement. At a micro scale four types of silcretes may be identified: grain supported fabric (quartzitic and conglomeratic silcretes) or fabrics with more than $40 \%$ silica cement and either quartzose, chalcedonic or opaline (porcellanite and terrazzo silcrete). Silcretes tend to form through a variety of mechanisms; hence no single model is universally acceptable (Watson and Nash, 1997). Thiry (1997) outlines details in climate, landscape dynamics, geochemistry and crystal growth as pivotal to understanding of silcretes. Three silicification processes were outlined: pedogenic (climates alternate between humid and dry, and $\mathrm{Si}$ in solution when wet and precipitates when dry); groundwater silicifications (develop at depth, away from climatic influences, $\mathrm{Si}$ moved in groundwater, silcretes arise due to groundwater lowering after landscape dissection, hence the silicifications are diagnostic of dissected terrain); and evaporate silicifications (due to mixtures of brine and fresh waters containing $\mathrm{Si}$, brines greatly reduce $\mathrm{Si}$ solubility, silcretes diagnostic of restricted environments and arid climates) (Thiry, 1997).

Ferricretisation of sediments of the duricrust suites and pans: Ferricretes are the least abundant of the duricrusts in Botswana. They may be mainly found in the eastern fringe of the country (Carney et al., 1994). Despite their limited occurrence in the Kgalagadi region, these occur on Letlhakeng valley 1. Another occurrence has been noted at Lekwatsi Pan (NE of Mochudi), Thomas and Shaw (1991). Ferricretes in the Letlhakeng valley were dominated by goethite and hematite minerals, as well as the quartz from the sandy host material. Iron may have migrated downslope in former wetter and probably cooler conditions than the present. The reverse relief model of landscape evolution would explain the ferricretes. Calcrete and silcrete both believed to have evolved through groundwater mechanisms (Nash et al., 1994) and the general valley and Kalahari development considered to be depositional rather than erosional (Thomas and Shaw, 1991), the groundwater lowering model of ferricrete formation at Letlhakeng may be favoured. Landscape lowering of valley must have led to Fe precipitating out, as groundwater subsided. Fe oxide movement in soils or landscape may be due 
to clay migration or surface erosion; reduced or redissolved by complexation with organic compounds (Cornell and Schwertmann, 1996).

The goethite tends to form in aerobic and anaerobic soils of all regions, while hematite is favoured in aerobic soils of sub-tropical, Mediterranean and humid to sub-humid tropical regions. To form goethite, $\mathrm{Fe}$ may be derived from several $\mathrm{Fe}$ compounds including silicates, carbonates and sulphides, after which oxidation occurs. Goethite may also form from the precursor mineral, ferrihydrite (metastable). The high thermodynamic stability of goethite makes it one of the commonest Fe oxide minerals in soils (Cornell and Schwertmann, 1996). Hematite has similar thermodynamic stability as goethite, but favours warmer climates. Hematite rarely occurs alone, but is associated with goethite (Cornell and Schwetmann, 1996).

Environmental issues in the formation of sediments of the duricrust suites and pans: Field relations of these indurated materials, was also sought, so as to establish their chronological sequence of formation. Mineralogical determinations of the valleys and pans have shown quartz to be the most abundant mineral. The most occurring duricrust is calcrete. Silcrete tended to underlay the calcrete, and the predominant mineral being quartz, with some opal occurring only in the Letlhakeng valley. Ferricretes were encountered only in Letlhakeng. The floor pan clay samples had occasional occurrences of clay minerals.

The Kalahari setting duricrust formation is more of the accumulation (e.g. sub-aerial processes), rather than erosional (Thomas and Shaw, 1991). The duricrusts may follow precipitation gradient ferricretes in northern, with calcretes and silcretes in the Kalahari core. Indurates may also be associated with landforms e.g. pans and drainage lines. The duricrusts may form through surface water ponding and groundwater systems; deep weathering mechanisms; salts and organics. Several of the lateral transfer models e.g. lacustrine/pan (high evaporation, alternating $\mathrm{pH}$ within a pan or lake) and groundwater models (fluctuation of water table, capillary fringe evaporation, and lateral throughflow) may result in indurates forming (Nash et al., 1994). In Letlhakeng valley, the duricrust formation has been linked to groundwater flow beneath valley floors, in former times of high water tables.

According to Nash et al. (1994) silcretes in Letlhakeng are a result of direct silica precipitation and cementation on a quartz host material, and not passive replacement of pre-existing bedrock; and the calcretes have an authigenic nodular to massive micromorphology typical of groundwater calcretes. The groundwater may be fresh, as indicated by freshwater bivalves in Letlhakeng (Nash et al., 1994) and in the Kalahari beds of Matsheng due to meteoric water recharge (Molwalefhe, 2001). The calcretes and silcretes, may accumulate through void filling (Nash et al., 1994) and the model of Molwalefhe (2001) advances scavenging of calcite, $\mathrm{SiO}_{2}, \mathrm{~N}_{2}$ gas, and the exchanger sites of $\mathrm{Ca}^{2+} / \mathrm{Na}^{+}$(release of $\mathrm{Na}^{+}$to solution) and $\mathrm{Na}^{+} / \mathrm{Mg}^{2+}\left(\mathrm{Na}^{+}\right.$uptake by exchange complex) to be associate with calcretisation. The real environmental setting, is complex due to several geochemical pathways, changing endogenic and exogenic conditions, which could lead to geomorphological evolution of the duricrusts.

In concluding, field relations of the various duricrusts are noteworthy. The order of duricrust sequences is that of calcrete, overlying silcrete, in most of the pans investigated. The various pans have similar mineralogy - they are dominated by calcite, quartz and dolomite. The latter would indicate evaporative conditions under warm standing water environment (Holmgren and Shaw, 1995). Calcrete rims, typical of the pans, tend to be dominated by the three minerals. The silcrete layer is mainly quartz. Samples from Khakhea, Khonkhwa, and Keng pans yielded mainly calcite, quartz and/or dolomite, with the clayey material consisting of either montmorillonite-15A or sepiolite. Usually pans are assumed to contain a lot of clay. The results here support those of Holmgren and Shaw (1995) that what may be taken as pan floor clay, could in reality be clay size material like very fine quartz and calcite.

Acknowledgement: Special thanks go to Messers G. Koorutwe and O. Okatswa, University of Botswana, for cartographic assistance.

\section{REFERENCES}

Carney, J.N.; Aldiss, D.T. and Lock, N.P. (1994) The geology of Botswana. Geological Survey Department, Bulletin 37.

Cornell, R.M. and Schwertmann, U. (1996). The iron oxides: structure, properties, reactions, occurrence and uses. VCH Verlagsgesellshaft, Weinheim, Germany.

Holmgren, K. and Shaw, P. (1995) Palaeoenvironmental reconstruction from nearsurface pan sediments: an example from Lebatse Pan, southeast Kalahari, Botswana. Late Pleistocene climatic and environmental changes 
in central southern Africa - Paper IV of PhD thesis. Stockholm University.

Molwalefhe, L.N. (2001) Geochemical characterization and origin of saline groundwater in shallow aquifers of SW Botswana. Botswana Journal of Earth Sciences, 5: 21-29.

Nash, D.J.; Shaw, P.A. and Thomas, D.S.G. (1994) Duricrust development and valley evolution: process-landform links in the Kalahari. Earth Surface Processes and Landforms, 19: 299-317.

Netterberg, F. (1978) Dating and correlation of calcretes and other pedocretes. Transactions of the Geological Society of South Africa, 81: 379391.

Ollier, C.D. (1978) Siclrete and weathering. In: T. Langford-Smith (Eds) Silcrete in Australia. Department of Geography, University of New England, p13-17.

Taylor, R.G. and Howard, K.W.F. (1999) Lithological evidence for the evolution of weathered mantles in Uganda by tectonically controlled cycles of deep weathering and stripping. Catena 35, 65-94.

Thiry, M. (1997) Continental silicifications: a review. In: Paquet, H. and Clauer, N. (Eds) Soils and sediments - mineralogy and geochemistry. Springer, Berlin, p191-221.

Thomas, D.S.G. and Shaw, A.P. (1991) The Kalahari Environment. Cambridge University Press. Cambridge.
Twidale, C.R. (2002) The two-stage concept of landform and landscape development involving etching: origin, development and implications of an idea. Earth-Science Reviews, 57: 37 -74.

Twidale, C.R. and Bourne, J.A. (1998) The use of duricrusts and topographic relationships in geomorphological correlation: conclusions based in Australian experience. Catena, 33: 105-122.

Watchman, A.L. and Twidale, C.R. (2002) Relative and 'absolute' dating of land surfaces. EarthScience Reviews, 58: 1-49.

Watson, A. and Nash, D.J. (1997) Desert crusts and varnishes. In: Thomas, D.S.G. (Ed.) Arid zone geomorphology: process, form and change in drylands, $2^{\text {nd }}$ Edition. John Wiley and Sons. Chichester, p69-107.

Wright, V.P. and Tucker, M.E. (1991) Calcrete: an introduction. In: Wright, V.P. and Tucker, M.E. (Eds) Calcretes. Blackwell Scientific. Oxford, p1-6.

Yapp, C.J. (2000) Climatic implications on surface domains in arrays of $\mathrm{D}$ and 180 from hydroxyl minerals: goethite as an example. Geochimica et Cosmochimica Acta, 64(12), 2009-2025.

Young, R.W.; Cope, S.; Price, D.M.; Chivas, A.R. and Chenhall, B.E. (1996) Character and age of lateritic weathering at Jervis Bay, southern New South Wales. Australian Geographical Studies, 34(2): 237-246. 